${ }^{1}$ Chair in Community Approaches and Health Inequalities, CHSRF/CIHR

${ }^{2}$ Groupe de recherche interdisciplinaire en santé, Université de Montréal, Canada

${ }^{3}$ Community Health Sciences, University of Calgary, Canada

${ }^{4}$ Coalition montréalaise des tables de quartier de Montréal, Canada

${ }^{5}$ Direction de santé publique de Montréal, Canada

\title{
Forum
}

\section{Structuring an Inter-sector Research Partnership: A Negotiated Zone}

\author{
Submitted: 8 June 2005 \\ Accepted: 1 August 2006
}

Summary

Objectives: To document and analyze the initial steps in building a health research partnership. To enable a greater appreciation of what these processes entail and also to provide guidance in negotiating the inevitable tensions between parties with different aims and objectives.

Methods: This case study is based on participant-observation and document analysis. It employed three general analytic strategies: developing a case description, relying on theoretical propositions and thinking about rival explanations.

Results: The development of a research partnership framework entails a complex negotiation process marked by tensions: one of representing the interests of the various parties; and one establishing the basis for collaboration. Some factors can facilitate these processes: acknowledging the specific interests and organizational culture of the various organizations involved; designating a mediator to develop a climate of trust; and mitigating the inequalities among partners, in a process which requires considerable efforts over a rather long period of time.

Conclusion: The process of structuring the relations among the associated partners does not end with negotiating a partnership accord. Denying this would be tantamount to denying the political nature of a research partnership, and denying those involved any autonomy in future research projects.

Keywords: Research partnership - Coalition building - Collaborative participatory research - Case study - Participant-observation.

In the field of health promotion and social development, there is a concern with enhancing and promoting participation in health research of members of the populations concerned. Authors present the goals or particularities of various approach- es in developing participatory research and draw out their premises or underlying principles, ethical issues, and challenges arising from trying to share power in egalitarian ways among the various partners (Park 1993; Israel et al. 1998; Reason 1994; Green et al. 1995; Allison \& Rootman 1996; Mason \& Boutilier 1996; Hagey 1997; Santiago-Riviera et al. 1998; Riley et al. 2001; Sullivan et al. 2001). Although there is a huge literature on participatory action research and community-based research in health promotion (Flynn et al. 1994; Green et al. 1995; Israel et al. 1998; Dallaire 2002), there is little published that documents and analyzes such processes, which could enable a greater appreciation of what these partnership-building processes entail. A few case studies documenting the establishment of health research centers in low-income neighborhoods in large American cities were based on retrospective, semi-structured interviews with active participants and on documents such as field notes, meeting minutes, funding applications and annual reports (Eisinger \& Senturia 2001; Freudenberg 2001; Lanz et al. 2001). It remains to be seen whether documenting and analyzing specific health research partnerships, as they unfold, might yield additional insights and also provide guidance in negotiating the inevitable tensions between parties with different aims and objectives.

The present paper documents and analyzes the initial steps in building a health research partnership under the auspices of a university chair, whose title is "Community Approaches and Health Inequalities." It is one of 12 research and training chairs created under the auspices of the Canadian Health Services Research Foundation (CHSRF, 2002), with a view to capacity building - bringing in new researchers to contribute to applied health services and policy research and increasing the uptake of research in health systems. The Chair's mandate is "to create a research program that will document and assess the role of public health programs based on social 
development in urban districts, in reducing social health inequalities" (Potvin et al. 2002). The accomplishment of its mandate requires the cooperation between public institutions, communitybased networks and researchers in order to conduct collaborative and participatory research with residents, neighborhood organizations and service providers within the Greater Montreal area.

Given the paucity of detailed research into the negotiation and development of research partnership frameworks to guide such partnership building process, the various organizations associated with the Chair agreed to allowing the steps leading to the structuring of their partnership to be the focus of a prospective case study. In line with our objectives, this is a participatory research project: the people who were directly involved in the negotiation, thus producing the data, also participated in analyzing the findings.

\section{The context}

The choice of the Chair's institutional partners seemed clear right from the beginning. A cooperative relationship had already been established with one of these partners, namely the Montreal Public Health Department (MPHD), in the process of securing funding for the Chair (Potvin et al. 2002). The City of Montreal and Centraide of Greater Montreal (United Way) who collaborate with MPHD in funding a social development program supporting neighborhood coalitions, also accepted the invitation to participate in the Chair's research partnership. More generally, by inviting these institutions to become its partners, the Chair hoped to promote the transfer and uptake of research findings on social development and health inequalities into their regular programs at the regional level. As the Chair privileged the creation of partnerships with networks directly involved into local development, it was also deemed important to invite a network of publicly funded Local Community Health and Social Services Centers, or CLSCs. ${ }^{1}$

Building rapport with community organizations represented the most significant challenge in establishing the Chair. Emphasis was placed on neighborhood-based organizations, which are regrouped under the Montreal Regional Coalition of Neighborhood Organizations ${ }^{2}$, and the Community Economic Development Corporations of Montreal (CDEC) $)^{3}$. Contacts were also made with other networks whose members deal with living conditions in low-income neighborhoods. The Coalition on Hunger and Social Development for Metropolitan Montreal $^{4}$, which has over 70 member organizations, rapidly displayed a keen interest in working with the Chair (Tab. 1).

\footnotetext{
${ }^{1}$ Centres locaux de services communautaires (CLSC).

${ }^{2}$ Coalition Montréalaise des Tables de quartier.

${ }^{3}$ Les Corporations de développement économique communautaire (CDÉC) de Montréal.

${ }^{4}$ La Table de concertation sur la faim et le développement social du Montréal métropolitain.
}

Table 1 The CACIS Governance structure. Organizational partners represented on the Advisory committee

$$
\text { Institutional partners }
$$

Montreal Public Health Department.

The MPHD mandate includes: ongoing monitoring of the state of public health, health and well-being promotion, prevention, health protection; it sports an integrated, concerted approach.

City of Montreal Department of Income security and Social Development

In cooperation with other municipal stakeholders, the department identifies issues and needs, develop strategies and proposes solutions including elaboration of municipal guidelines for social development as well as negotiations and the followup of metropolitan social programs.

- Centraide of Greater Montreal (United Way)

By conducting a vast annual fundraising campaign and by financing a network of community agencies and projects this organization helps some 500000 people in need or in difficulty

- Coalition of Montreal Local Community Health Centers (CLSC)

29 publicly funded health and social services centers for individuals and families - the representative was appointed by the Table of CLSC Directors

\section{Community partners}

Montreal Regional Coalition of Neighborhood Organizations 29 Neighborhood networks on the Island of Montreal working on various issues such as low-cost housing, local development, fight against poverty, support for families, youth, elders, integration of marginal population, public health, urban security, etc. represented by two (2) members of their Executive.

- Montreal Network of Community Economic Development Corporations (CDEC)

Inter-sector local corporations active in job creation, employability and local economic development having representatives of local business, unions and community networks on their boards.

- Coalition on Hunger and Social Development for Metropolitan Montreal

Network of 80 organizations active on food security, poverty, education and environment represented by the Chair of their Board of Directors

\section{Research partners}

The Chair of CACIS, professor-researcher at the Department of Social and Preventive Medicine, University of Montreal - Ph.D. in Public Health.

- Professor-researcher at the Department on Urbanization, Culture and Society, National Institute of Scientific Research (INRS) - Ph.D. in economics and sociology.

Professor-researcher at the Department of Sociology, University of Montreal and Director of a research Center in a CLSC in Montreal - Ph.D. in sociology.

Director of Graduate Diploma in Community Economic Development at the School of Community and Public Affairs, Concordia University - Ph.D. in social work. 
In fact, the organizations (community organizations and public institutions) invited to participate in the Chair's activities had established relationships with one another and were already influencing each other. Various partners in the Chair structure identified the variable nature of the collaboration among these organizations as a source of tension and some mistrust. For example, the Montreal Regional Coalition of Neighborhood Organizations had refused, in 1999, to participate in a research project to evaluate their work, which had been initiated by its funders - who were also the Chair's three largest institutional partners. The structure of the Chair had the potential to reinforce a pre-existing asymmetry of power. Interdependence and unequal access to resources and power among the organizations, a state of affairs which could certainly contribute to whether the Chair will meet its objectives, influenced how and when contacts were made.

\section{Research methods}

This case study relied mainly on participant-observation and document analysis. Three general analytic strategies are used in case study research (Yin 2002): developing a case description, relying on theoretical propositions and thinking about rival explanations. The present study employed all three of these analytic strategies. The detailed minutes of all the meetings, which were distributed to and adopted (following modifications and comments) by all participants, became the primary source of information for this study. A thematic analysis of this material was made using categories such as: expectations (research themes/research approach/expected benefits); positioning in negotiation (emphasis on self interest/common interest/compromise solution); reference to context (relations, constraints, previous or associated experiences); rules and regulations of partnership (flexibility, reciprocity, obligations, decision process). In addition, shortly after each meeting, the coordinator (first author) wrote up supplementary observations, with help from a socio-cultural anthropologist (second author) associated with the Chair but not directly involved in structuring the partnership framework. Informed by the guide Writing Ethnographic Fieldnotes (Emerson et al. 1995), these notes documented situations, gestures and interactions that helped shape the negotiation processes (e.g., verbal and non-verbal behavior; sequence and frequency of interventions by the first author and others involved in the Chair structure). Fieldnotes documenting what has been learned or noted through participant-observation allow researchers to consider events or interactions that would otherwise remain inaccessible to investigation because they are not necessarily reported in the minutes, and because they can be glossed over, ignored or reinterpreted in retrospective interviews. In the present case study, participant-observation permitted the processes involved in structuring a research partnership to be documented, as these processes unfolded.

A literature review, commissioned under the auspices of the Chair, on the establishment of collaborative frameworks in participatory approaches to research (Dallaire 2002) was useful in planning our approach to structuring a research partnership and in our analysis of this case. This literature review helped to situate the Chair's emergent characteristics with respect to various theories of participatory action research and to collaborative frameworks between researchers and community representatives in social development research. Moreover, in developing theoretical propositions, our analysis was informed by Crozier and Frieberg's work (Crozier \& Friedberg 1977; Friedberg 1997) on power dynamics inherent to the structuring of collective action.

Rival accounts were sought by circulating previous drafts of this article and supporting materials among the authors. Rival accounts were also identified by circulating documents, such as minutes and summaries, to participants in the negotiation process who were not involved in preparing the present text. The analysis thus draws upon a broader range of rival accounts than could have been generated collectively by this group of authors representing different partners.

The analysis paid special attention to the "critical incidents" revealing the existing or sought after relations with certain partners who contributed to elaborating the partnership agreement. A chronology was produced showing various activities carried out under the auspices of the Chair, and this chronogram was used as a reference in the analysis phase to place the key developments in sequence (Tab. 2). Our analysis focuses on the contextualization of these critical events, with a view to providing a better understanding of pre-existing dynamics and how the individuals and organizations involved in structuring the Chair sought to position themselves. In participant-observation research, critical incidents have often been analyzed to understand interactions among the various actors, including the researchers (Le Compte \& Schensul 1999; Emerson et al. 1995; Smith 1999; Mykhalovskiy \& McCoy 2002). While uncommon (by definition), these events merit careful documentation and analysis because they reflect and may influence the interactions among the actors.

Our observations and analysis were carried out as a group in the context of a collaborative participatory research. One author representing community organizations and one from an institutional setting participated in the process and provided comments on the preliminary versions of this article. The academic selected to fill this Chair supervised all the activities, participated in most of the meetings and contributed directly to the analysis. This permitted the investigation to be informed by more than one inside perspective, since four of the five authors of this arti- 
Table 2 Chronology

\begin{tabular}{|c|c|}
\hline Sept.-Dec. 2001 & $\begin{array}{l}\text { Development of the Chair communications tools; } \\
\text { Contact with potential partners and investigation of their interests }\end{array}$ \\
\hline Sept.-Oct. & $\begin{array}{l}\text { Development of the mandate and composition of an Advisory Committee and validation with the initial partner: } \\
\text { Montreal Public health Department - MPHD }\end{array}$ \\
\hline Sept.-Oct. & Meetings with local neighbourhood networks and validation of a synthesis of exchanges on points of view. \\
\hline Sept.-Oct. & Production of publicity material: logo, leaflet \\
\hline November $5^{\text {th }} 2001$ & Chair Official Launch \\
\hline Sept.-Dec. $8^{\text {th }}$ & Web Site on line \\
\hline Nov.-Dec. & Identification of/invitation to/Meeting with potential members of the Advisory Committee \\
\hline Nov.-Dec. & $\begin{array}{l}\text { Contacts with various community networks (Community Economic Development Corporations - } \\
\text { CDEC, Coalition on Hunger and Social Development - TCFDS) }\end{array}$ \\
\hline Nov.-Dec. & Contact established with the Coalition of Montreal Local Community Health Centers - CLSC \\
\hline Jan.-Sept. 2002 & Creation of a Multi-partner Advisory committee; negotiation of a partnership agreement \\
\hline January $10^{\text {th }} 2002$ & $\begin{array}{l}1^{\text {st }} \text { meeting of the Advisory Committee; discussion of its mandate; creation of a committee to negotiate a } \\
\text { partnership agreement }\end{array}$ \\
\hline Jan.-April 2002 & $\begin{array}{l}\text { Meetings with other networks: Jan. } 19^{\text {th }}: \text { Metropolitan Montreal Development Council; Jan. } 30^{\text {th }} \text { : Inter-sectoral } \\
\text { Coalition of Community Organizations; Feb, } 6^{\text {th }}: \text { Quebec Coalition of Community Organizers in CLSCs; April } 30^{\text {th: }} \text { : } \\
\text { Montreal Coalition of Women's Centers }\end{array}$ \\
\hline Feb.-March 2002 & $\begin{array}{l}\text { Meetings with local neighbourhood networks not present at the first meetings in the autumn: Feb. } 7^{\text {th }} \text { : } \\
\text { Mercier-est; March } 5^{\text {th }} \text { : Parc-extension; March } 19^{\text {th }} \text { : Pointe-est de l'île de Montréal }\end{array}$ \\
\hline Feb.-March 2002 & $\begin{array}{l}\text { Occasional support for activities and the development of research projects. Feb. } 14^{\text {th }} \text { : Conference at TCFDS; } \\
\text { March } 12^{\text {th }} \text { : Meeting with ROSAC-MPHD }\end{array}$ \\
\hline Feb.-March 2002 & $\begin{array}{l}\text { Request to Centraide (the United Way) for financial support to compensate community network representatives } \\
\text { for their preparation /participation in the negotiation process }\end{array}$ \\
\hline March-May 2002 & Survey of CLSCs on their needs in research \\
\hline March $13^{\text {th }} 2002$ & $\begin{array}{l}1^{\text {st }} \text { negotiation meeting on the partnership agreement } \\
\text { Positioning of self-interests }\end{array}$ \\
\hline April $10^{\text {th }} 2002$ & $\begin{array}{l}2^{\text {nd }} \text { negotiation meeting on the partnership agreement } \\
\text { Emerging tensions/identifying key issues }\end{array}$ \\
\hline May $1^{\text {st }} 2002$ & $\begin{array}{l}3^{\text {rd }} \text { negotiation meeting on the partnership agreement } \\
\text { Negotiating detailed partnership agreement }\end{array}$ \\
\hline May $23^{\text {rd }} 2002$ & $\begin{array}{l}2^{\text {nd }} \text { meeting of the Advisory Committee; adoption of its mandate; presentation and debate on a draft of the } \\
\text { Partnership agreement; report on the CLSC survey; proposal of a public forum }\end{array}$ \\
\hline Oct. 02-April 03 & $\begin{array}{l}\text { Adoption of a Partnership agreement; preparation of a multi-partner research proposal and application for } \\
\text { granting; Chair Public Forum. }\end{array}$ \\
\hline October $31^{\text {st }} 2002$ & $\begin{array}{l}3^{\text {rd }} \text { meeting of the Advisory Committee; Discussion/adoption of the research partnership agreement by the Advisory } \\
\text { Committee. }\end{array}$ \\
\hline October 2002 & Preparation of a multi-partner research proposal and application for $1^{\text {st }}$ grant \\
\hline November $8^{\text {th }} 2002$ & Public Forum on: Research and action: what kinds of relations? \\
\hline April $22^{\text {nd }} 2003$ & $\begin{array}{l}4^{\text {th }} \text { meeting of the Advisory Committee; grant announcement and discussion of the implementation of the research } \\
\text { program; summary and follow-up of the Forum }\end{array}$ \\
\hline May 2003 & Implementation of the research program; multi-partner workshops and development of various research projects \\
\hline
\end{tabular}

cle actively participated in establishing the research partnership for the Chair. These people and the coordinator could all influence the course of events. In addition, the role undertaken by an additional researcher associated with the Chair but not in the partnership negotiation process brought an external perspective to bear in this case study. Given the authors' distinct roles and points of view on the negotiation process, the collective prepa- ration of this article gave rise to many dialogues about what had transpired, and made for a more comprehensive account.

\section{Structuring the partnership}

As it stands, the public and community partners do not all have an equal say in shaping research agendas and interpreting research results. Their powers, responsibilities and obliga- 
tions differ considerably. Certain partners are able to influence priorities in the production of knowledge, such that the communities involved in research, evaluation research in particular, may feel that their autonomy is threatened. Moreover, the public institutional partners have access to more resources and power than the neighborhood-based organizations. By comparison, the neighborhood-focused organizations were being invited to enter into a partnership with institutions that were funding them and were experiencing an unstable situation. At the time, neighborhood-focused organizations were negotiating with the Quebec government over how a policy (adopted in autumn 2001) of recognition and financial support for community action would actually be implemented. The main issues at stake in structuring the Chair's research partnership were the goals and use of evaluation, and the validity and reliability of research and evaluation results in relation with the autonomy of community organizations.

Making contact and engaging partners. Separate meetings were scheduled with each of the eventual partners. These initial meetings served to identify the potential partner's respective points of view on the Chair's research theme; to listen to their concerns with regard to how the partnership would be structured; and to invite them to participate in an advisory committee, the mandate of which would be jointly defined by all the partners. This approach was adopted in an attempt to acknowledge each of the partner's potential contributions, to respect their respective organizational cultures and to limit the areas of uncertainty that could appear threatening to them. Meetings were convened with as many coordinators of neighborhood networks as possible (18 of the 21 local coordinators), so as to take into account the more decentralized operation of this coalition as well as expressed feelings of resistance. For the other community networks, contact was made at the regional coordination level, whose staff, in turn, consulted the member groups and designated a representative.

Two factors eased the initial contacts. First, the process adopted helped balance the needs and expectations of the community networks with the expectations of the institutional partners, from whom the community networks were routinely obliged to seek funding. This approach, by addressing uncertainty among the neighborhood-based networks, helped structure the Chair. Moreover, the Chair coordinator issued from community networks also acted as a mediator to develop a climate of trust throughout the process.

Second, asymmetries in access to resources among the community-based and institutional partners needed to be taken into account in developing the Chair's partnership arrangements. Since the negotiation of a partnership agreement makes significant demands on organizations, it was important to ensure that the more vulnerable groups would have access to the resources necessary for them to participate fully. The Chair thus requested and received support from one of the institutional partners, Centraide of Greater Montreal (United Way). The Chair was thus able to provide financial compensation to the representatives of the community groups, in order to support them in preparing and participating in the negotiations that led to a partnership accord.

The main body guiding the overall development of the Chair's activities is an advisory committee. This committee is composed of representatives from three sub-groups (namely, public institutions, community networks and the research community), each of which is represented by four people (Tab. 1). The purpose of having an equal number of representatives for each subgroup was to foster balance in the expression of points of view with a possibility of influencing the Chair's program.

A task force was created to negotiate a research partnership framework; they met three times and reported to the advisory committee to conclude the negotiation process. It was composed of six persons: the academic named to the Chair, the coordinator for the Chair, two representatives coming from the main community network partners (Montreal Regional Coalition of Neighborhood Organizations and Community Economic Development Corporations regional network), and two representing institutional partners: a representative of the Montreal CLSC network, and a single representative for the three partners that were jointly funding a social development program in Montreal and had a common interest in evaluating the impact of their intervention.

The negotiation process. The afore-mentioned literature review on partnership frameworks was distributed to the participants before the task force first meeting in order to help the members move beyond their previous interactions with one another, and focus on the objectives of elaborating a partnership agreement in a climate conducive to frank and constructive negotiations. Commenting on participatory research, the person representing the Regional Coalition of Neighborhood Organizations said that the partnership framework must explicitly acknowledge that local communities could refuse to associate themselves with a given research project, and also that they could propose research projects. He also said that the partnership framework should oblige the researchers to share their data with a community under study, so that this community's members could draw and publicly express their own conclusions. This statement, at the outset of the negotiating process, illustrated the influence sought by this partner in the Chair's research activities, on the basis of their own interests and assets and was analyzed as a first "critical event". It was 
then agreed that, before the next meting, each representative would consult his or her respective network in order to be able to articulate expectations and worries with regard to the research program to be developed.

At the second meeting, the former tensions between the Montreal Regional Coalition of Neighborhood Organizations and its sponsors were then brought to the surface in this debate. The representative of the three institutions funding a social development program in Montreal summarized the results of the consultation between these partners. This document reiterated these partners' interest in participating in research on multisector and multi-network collaboration. It also noted that these organizations "had particular expectations with regard to the Chair's contribution to developing indicators for monitoring and evaluating local coalitions' initiatives and their impact on health" (Bujold 2002 [our translation]). The representative of the Coalition of Neighborhood Organizations challenged this position. He feared that the community-based organizations would be put in an even more precarious position if the issue of evaluating the performance of local coalitions was on the agenda, saying that he would have to withdraw, for he was not mandated to defend member organizations' respective interests vis-à-vis funding agencies, but to participate in research that could lead to effective strategies for reducing population health disparities in Montreal.

The Chair-holder then insisted that the goal of an evaluative research is not to decide whether or not to maintain a program but to examine each partner's practices, considering that all of them are decision makers in the context of a negotiated research agenda. This statement is analyzed as a second "critical event" as it helped the task force to focus on key issues: how to ensure acceptability of the project for the local organizations and neighborhoods involved and to respect minorities; how to deal with the issue of confidentiality in participative research. Other points were raised in relation to the sensitive issue of nominative identification of poor urban neighborhoods; and the importance of communicating the results to the participants and discussing potential actions with them before any larger diffusion or publication.

At the third negotiation meeting, some results were presented from a survey of CLSC network. The respondents indicated a solid support for local coalitions, but a lack of resources and support by public health authorities in this aspect of their mission. A concern was expressed about the chronic instability in terms of resources and staff in community organizations and the need to support their participation as partners in research. It was subsequently agreed to include in the research partnership framework that all partners would share the responsibility of ensuring the necessary support to ensure equal participation for community organizations. This was critical to engage all partners in negotiating detailed agreement. At this meeting, the partners also tackled delicate topics such as public dissent and responsibility for realizing recommendations arising from various research projects. This discussion led to stipulating that different arrangements might have to be put in place regarding flexibility in the partnership agreement.

After circulating the framework proposed by the task force to the various partners, the Chair's advisory committee discussed further several points. The researchers who had not been involved in the negotiation task force raised many additional concerns which were critical for the acceptance of the framework by the scientific community: the confidentiality of and access to data sources when local representatives are associated with the research; the independence of the researchers and the participation of local actors in data analysis; the importance of associating all the partners at the moment of project formulation; and the goals of the research and its relationship to social action. This discussion brought about further modifications to the partnership framework before adoption at the following meeting of the advisory committee.

The partnership framework. The Chair's partnership framework is a first result of this negotiation process. It has four parts: a mission statement; a presentation of the values and guiding principles; a list of the roles and obligations of each kind of partner (researchers, community networks, public administration); and a tool to help guide the elaboration of research projects (CACIS 2002).

The mention of goals and values makes it possible to situate the contributions and expectations of the people and organizations collaborating in the research activities. Well aware that research is not exempt from debates over values with regard to approaches and goals, the framework aims to respect "the values, beliefs and people and organizations coexisting in local settings ... [and] as much as possible foster the development of [their] abilities". It sets out shared responsibility among the various partners to help ensure respect for all parties, to adhere to standards for the ethical conduct of research, and to find financial support to enable the participation of representatives of the community or local organizations.

The statement of the roles and obligations for each kind of partner has a symmetrical form (Tab. 3) and reflects an expectation of reciprocity, without aiming at an overly constraining framework that would leave little autonomy for the partners involved in specific research projects. With regard to its application, it was decided to delegate this responsibility to the actors directly involved in a research project, providing a guide to help the integration of these commitments into the research activities. 
Structuring an Inter-sector Research Partnership:

A Negotiated Zone

Table 3 Partnership Framework Roles and obligations of the partners of the CHRSF/CIHR Chair in Community Approaches and Health Inequalities

\begin{tabular}{|c|c|c|}
\hline Researchers & Community Partners & Institutional Partners \\
\hline $\begin{array}{l}\text { 1. Conduct research of benefit to the } \\
\text { population and do nothing against its } \\
\text { interests. } \\
\text { 2. Ensure that the research plan, the analysis } \\
\text { and the interpretation of the findings } \\
\text { meet recognized standards and are } \\
\text { socially and culturally acceptable for the } \\
\text { population concerned. } \\
\text { 3. Encourage the partners' active } \\
\text { participation in the research and transmit } \\
\text { new abilities to them. } \\
\text { 4. Assume the responsibility for jointly } \\
\text { finding resources to support the } \\
\text { participation of researchers from the } \\
\text { community. } \\
\text { 5. Ensure that the findings are made } \\
\text { available in an accessible form to the } \\
\text { partners and provide the expertise to } \\
\text { answer questions from the population. } \\
\text { 6. Support the community's efforts in } \\
\text { dealing with all social and health } \\
\text { questions raised by the research. } \\
\text { 7. Promote the academic diffusion } \\
\text { of the findings in publications and } \\
\text { presentations. } \\
\text { 8. Keep the data during the research and at } \\
\text { the end of the project, in conformity with } \\
\text { recognized standards and the agreements } \\
\text { negotiated with the partners. } \\
\text { 9. Where possible, accompany analysis } \\
\text { and intervention activities arising from } \\
\text { the research in collaboration with the } \\
\text { partners. } \\
\text { 10. Agree to discuss with the other partners } \\
\text { the interpretation of the findings and } \\
\text { the recommendations arising from } \\
\text { the research, with a view to creating a } \\
\text { consensus, and agree to the expression of } \\
\text { public dissent if disagreements persist. }\end{array}$ & $\begin{array}{l}\text { 1. Represent community members through } \\
\text { their organization and promote the } \\
\text { project's objectives by working with the } \\
\text { population and the other partners. } \\
\text { 2. Facilitate meetings between researchers } \\
\text { and community representatives in order } \\
\text { to consult them about the goals of the } \\
\text { research and to encourage collaboration. } \\
\text { 3. Support the project and represent the } \\
\text { realities of the community to foster a fit } \\
\text { between the goals of the research and } \\
\text { the needs of the population. } \\
\text { 4. Facilitate the regular participation of } \\
\text { the representatives and communicate } \\
\text { relevant recommendations. } \\
\text { 5. Assume the responsibility for finding } \\
\text { resources to support the participation of } \\
\text { researchers from the community. } \\
\text { 6. Contribute according to their resources } \\
\text { to all stages of the research until its } \\
\text { completion. } \\
\text { 7. Respond to requests for information } \\
\text { about the project's development and } \\
\text { effects in collaboration with the other } \\
\text { partners. } \\
\text { 8. Promote the diffusion of the findings } \\
\text { in the community and support the } \\
\text { population's actions arising from the } \\
\text { research. } \\
\text { 9. Collaborate in respecting the agreements } \\
\text { about access, confidentiality and } \\
\text { conservation of research data. } \\
\text { 10. Accompany analysis and intervention } \\
\text { activities arising from the research in } \\
\text { collaboration with the partners. } \\
\text { 11. Agree to discuss with the other partners } \\
\text { the interpretation of the findings and } \\
\text { the recommendations arising from } \\
\text { the research, with a view to creating a } \\
\text { consensus, and agree to the expression of } \\
\text { public dissent if disagreements persist. }\end{array}$ & $\begin{array}{l}\text { 1. Represent their organization and } \\
\text { promote the project's objectives by } \\
\text { working with the population and the } \\
\text { other partners. } \\
\text { 2. Facilitate meetings between researchers } \\
\text { and the community representatives } \\
\text { in order to consult them about the } \\
\text { goals of the research and to encourage } \\
\text { collaboration. } \\
\text { 3. Support the project and represent the } \\
\text { realities of the community to foster a fit } \\
\text { between the goals of the research and } \\
\text { the needs of the population. } \\
\text { 4. Facilitate the regular participation of } \\
\text { the representatives and communicate } \\
\text { relevant recommendations. } \\
\text { 5. Assume the responsibility for finding } \\
\text { resources to support the participation of } \\
\text { researchers from the community. } \\
\text { 6. Respond to requests for information } \\
\text { about the project's development and } \\
\text { effects in collaboration with the other } \\
\text { partners. } \\
\text { 7. Promote the diffusion of the findings } \\
\text { among decision makers and in their } \\
\text { institutional network. } \\
\text { 8. Support the actions of the population } \\
\text { arising from the research, to the extent } \\
\text { that their resources permit. } \\
\text { 9. Collaborate in respecting the agreements } \\
\text { about access, confidentiality and } \\
\text { preservation of research data. } \\
\text { 10. Accompany analysis and intervention } \\
\text { activities arising from the research in } \\
\text { collaboration with the partners. } \\
\text { 11. Agree to discuss with the other partners } \\
\text { the interpretation of the findings and } \\
\text { the recommendations arising from } \\
\text { the research, with a view to creating a } \\
\text { consensus, and agree to the expression of } \\
\text { public dissent if disagreements persist. }\end{array}$ \\
\hline
\end{tabular}

The partnership framework also privileges consensus with regard to the interpretation, the presentation and the dissemination of research findings. In practice, this commitment means that all the partners are to be given access to the findings before they are published. In cases of disagreement over the conclusions and recommendations, a partner cannot block the diffusion of the results, but the partnership framework affirms that all parties may express dissension publicly and have input in alternative interpretation as the findings are diffused. Lastly, the partnership framework stipulates that the partners collaborate in developing measures or action plans stemming from the research.

\section{Discussion}

The foregoing description of the development of a research partnership framework to support a university-based Chair reflects a complex negotiation process. The Chair's mission statement defined a negotiated zone. Reaching out to potential partners with just a mission statement for the Chair in hand permitted them to participate in structuring a research partnership. At the stage of the initial contacts with the potential partners, "what is important is not so much the clarity of the final objectives or the yet-to-be-structured mode of operating, but the creation of a dynamic through which guidelines and a new operating logic gradually emerge" (Friedberg 1997 [our translation]). The possibility of having a real, significant influence on the elaboration of a partnership agreement is an incentive to participation. In this case, for example, the Chair's academic teaching, training and mentoring mandates were set aside in negotiating a research partnership agreement, as they are subject to the university's institutional constraints.

The negotiation could not ignore the tension between two processes: one of representing, contrasting and furthering the interests of the various parties and their specific expertise with 
a view to establishing each member's scope of influence (as in 1st and 2nd task force meetings) and one establishing the basis for cooperation with a view to creating a new, composite entity and so achieve goals that are out of reach for each partner alone (as in $2^{\text {nd }}$ and $3^{\text {rd }}$ task force meetings). The result was a dynamic of "conflictual cooperation", which threads through and animated the negotiations. The role of the Chair's negotiators was then to regard all partners as social actors with specific interests and thus to emphasize common goals instead of inter-organizational conflicts and controversy. This facilitating role can be effective when based on sound knowledge of the actors' missions, organizational cultures, values and past relations.

The establishment of a research partnership faces many challenges: balancing the interests of communities, researchers, and public health institutional partners; sharing resources, responsibilities, and opportunities; and dealing with tensions between a commitment to process versus research products (Higgins \& Metzler 2001). There are also some factors that facilitate the structuring of a research partnership, including: the importance of acknowledging the specific interests and organizational culture that form the identity of the various organizations involved; the utility of a well informed mediator to develop a climate of trust throughout the negotiation process; the relevance of mitigating the inequalities among partners, in a process which requires considerable efforts over a rather long period of time.

In structuring a partnership agreement, power relationships emerge in interactions and negotiations and cannot be reduced to the attributes of each of the actors (resources, formal authority, etc.). For example, in this case study, after the partners had expressed an agreement with the principles of participatory research, the representative of a community network insisted on the right for a local neighborhood to refuse or propose a specific research project. This brought to the fore a capacity to mobilize certain sources of uncertainty as a resource in order to increase their influence in the partnership negotiation, compared to the capacity based strictly on their assets. The Chair's partnership agreement helped balance power positions in knowledge production, by supporting community networks in developing research proposals and by helping them to access senior researchers in order to implement collaborative and participatory research.

As with all efforts to organize collective action, the structuring of the Chair's research partnership is a specific and contingent arrangement that reflects its context, available re- sources, objectives capable of rallying the various actors, and the formal and informal rules governing the exchanges among them. While it may not be possible to generalize from our results to all subsequent attempts to build research partnerships, this case study did enable the identification of some dynamics that could usefully be taken into consideration. With regard to methodology, this study suggests that participant-observation research is useful for documenting the emergence of new collectivities and agreements, giving access to the dynamics of negotiation and the sequence of critical events as they unfold.

In closing, we must stress that the process of structuring the relations among the associated partners does not end with negotiating a partnership accord. Denying this would be tantamount to denying the political nature of a research partnership, and denying those involved, any autonomy in future research projects. But the impact of the negotiation process and the partnership agreement on subsequent activities and program achievements must be stressed. By developing relative but never assured relations of thrust between partners, this initial process founded future cooperation in research activities. The proof is in the pudding, that is, in the actual development of diverse research projects that are developed with these and other partners on the basis of the Chair's partnership agreement.

\section{Acknowledgements}

This study was made possible by a research grant jointly funded by the Canadian Health Services Research Foundation, the Canadian Institutes of Health Research and the Fonds de recherche en santé du Québec (CP1-0526-05). During the tenure of the study, Melanie Rock held a postdoctoral fellowship jointly funded by the Canadian Health Services Research Foundation and the Canadian Institutes of Health Research (PDA-0800-05).

The deliberations of a committee charged with negotiating the terms of a partnership between university-based researchers, a public health agency and community organizations form the basis of the present paper. The authors would like to thank the members of this committee: Diane Barbeau, Regroupement des Corporations de développement économique communautaire; Renald Bujold, Direction de la santé publique de Montréal-Centre; Clermont Racine, Regroupement des Centres locaux de services communautaires de Montréal; and Michel Roy, Coalition montréalaise des tables de quartier. 
Zusammenfassung

Das Strukturieren einer intersektoriellen Forschungspartnerschaft: eine ausgehandelte Zone

Zielsetzung: Die ersten Schritte auf dem Weg zu einer Forschungspartnerschaft im Gesundheitsbereich werden dokumentiert und analysiert. Dadurch soll ein größeres Bewusstsein für den Verlauf derartiger Prozesse geschaffen werden. Ein weiteres Ziel stellt eine Anleitung zum Aushandeln der unvermeidbaren Spannungen zwischen den jeweiligen Parteien mit unterschiedlichen Absichten und Zielen dar.

Methoden: Die Fallstudie basiert auf teilnehmender Beobachtung und Dokumentenanalyse. Drei generelle Strategien wurden angewendet: die Entwicklung einer Fallbeschreibung, das Abstützen auf theoretische Propositionen und der Einbezug konkurrierender Erklärungen.

Resultate: Die Entwicklung eines Frameworks für Forschungspartnerschaften steht für einen komplexen Aushandlungsprozess mit vielfältigen Spannungen: die Repräsentation der Interessen der involvierten Parteien und die Schaffung einer gemeinsamen Basis der Zusammenarbeit. Einige Faktoren können diese Prozesse vereinfachen: das Anerkennen der spezifischen Interessen und unterschiedlichen Kulturen der beteiligten Organisationen, die Bestimmung eines Mediators/einer Mediatorin, um ein Klima des Vertrauens zu schaffen, und die Abschwächung der Ungleichheiten zwischen den Partnern in einem Prozess, der von den Beteiligten beträchtlichen Einsatz fordert und sich über längere Zeit erstreckt.

Schlussfolgerungen: Der Prozess der Beziehungsgestaltung zwischen den Partnern ist mit dem Aushandeln eines Partnerschaftsvertrags nicht zuende. Dies zu bestreiten würde bedeuten, sowohl den politischen Charakter einer Forschungspartnerschaft wie auch die Autonomie der Beteiligten bei zukünftigen Forschungsprojekten zu verneinen.

\section{Résumé}

Structurer un partenariat de recherche intersectoriel: une zone négociée

Objectifs: Documenter et analyser les étapes initiales de la construction d'un partenariat de recherche dans le domaine de la santé. Améliorer la compréhension de ce qu'implique un tel processus. Fournir des pistes permettant de négocier les inévitables tensions apparaissant entre des parties disposant d'objectifs propres.

Méthodes: Cette étude de cas est basée sur l'observation participante et sur l'analyse de documents. Elle a recouru à trois stratégies analytiques générales: développer une étude de cas, utiliser des propositions théoriques, considérer des explications différentes.

Résultats: Le développement d'un cadre pour le partenariat de recherche reflète un processus de négociation complexe marqué par les tensions liées à la défense des intérêts des différentes parties et à la construction des bases d'une collaboration. Certains facteurs sont à même de faciliter ce processus: reconnaître les intérêts spécifiques ainsi que la culture organisationnelle des différentes organisations impliquées; désigner un médiateur de façon à mettre en place un climat de confiance et à homogénéiser les inégalités apparaissant entre les partenaires. Cette démarche nécessite des efforts considérables sur une relativement longue durée.

Conclusions: Ce processus de structuration des relations entre partenaires associés ne se termine pas avec la négociation d'un accord de partenariat. Nier cet état de fait reviendrait à nier la nature politique d'un partenariat de recherche et à refuser aux partenaires impliqués toute autonomie dans de futurs projets de recherche.

\section{References}

Allison KR, Rootman I (1996). Scientific Rigor and Community Participation in Health Promotion Research. Health Promot Int 11: 333-40.

Bujold R (2002). Attentes et rôles des partenaires. Montréal: DSP Montréal-Centre, Ville de Montréal, Centraide du Grand-Montréal (unpubl.).

CACIS (2002). Cadre de partenariat. Chaire Approches communautaires et inégalités de santé FCRSS/IRSC. http://www.cacis.umontreal. ca/cadredepartenariat.pdf
CHSRF (2001). Funded Programs and Funding Opportunities. Canadian Health Services Research Foundation (CHSRF).

http://www.chsrf.ca/cadre/

Crozier M, Friedberg E (1977). L'acteur et le système. Les contraintes de 1'action collective. Éditions du Seuil, Paris.

Dallaire M (2002). Cadres de collaboration des approches participatives en recherche: recension d'écrits. Chaire Approches communautaires et inégalités de santé, Montréal.

http://www.cacis.umontreal.ca/publi.htm
Eisinger A, Senturia K (2001). Doing Community-Driven Research: a Description of Seattle Partners for Healthy Communities. J Urban Health 78: 519-34.

Emerson RM, Fretz RI, Shaw LL (1995). Writing Ethnographic Fieldnotes. The University of Chicago Press, Chicago.

Flynn BC, Ray DW,Rider MS (1994). Empowering Communities -Action research through Healthy Cities. Health Educ Q 21(3): 395-405. 
Freudenberg $N$ (2001). Case History of the Center for Urban Epidemiologic Studies in New York City. J Urban Health 78: 508-18.

Friedberg E (1997). Le pouvoir et la règle. Dynamiques de l'action organisée. Éditions du Seuil, Paris.

Green LW, George M, Daniel M et al. (1995). Study of Participatory research in Health Promotion: Review and Recommendations for the Development of Participatory Research in Health Promotion in Canada. Ottawa: The Royal Society of Canada.

Hagey RS (1997). La recherche participative: utilité et abus. Maladies chroniques au Canada 18: $1-5$.

Higgins DL, Metzler M (2001). Implementing Community-Based Participatory Research Centers in Diverse Urban Settings. J. of Urban Health 78: 488-94.

Israel BA, Shulz AJ, Parker EA, Becker AB (1998). Review of Community-Based Research: Assessing Partnership Approaches to Improve Public Health. Ann Rev Public Health 19:173-202.

Lanz PM, Viruell-Fuentes E, Israel BA et al. (2001) Can Communities and Academia Work Together on Public Health Research? Evaluation Results from a Community-Based Participatory Research Partnership in Detroit. J Urban Health 78: 495-507.
LeCompte MD, Schensul JJ (1999). Designing and Conducting Ethnographic Research. Ethnographer's Toolkit. Vol. 1. Walnut Creek: AltaMira Press.

Masson R, Boutilier M (1996). The Challenge of Genuine Power Sharing in Participatory Research. The Gap between Theory and Practice. Can J Community Mental Health 15: 145-52.

Mykhalovskiy E, McCoy L (2002). Troubling Ruling Discourses in Health: Using Institutiona Ethnography in Community-Based Research. Critical Public Health 12: 18-37.

Park P (1993). What is Participatory Research? A Theoretical and Methodological Perspective. In: Park P, Brydon-Miller M, Hall B, Jackson T (eds.). Voices of Change. Participatory Research in the United-States and Canada. Toronto: The Ontario Institute for Studies in Education.

Potvin L, Lessard R, Fournier P (2002). Inégalités sociales de santé: un partenariat de recherche et de formation. Rev Can de santé publique 93: 134-7.

Reason P (1994). Three Approaches to Participatory Inquiry. In: Denzin NK, Lincoln YS (eds). Handbook of Qualitative research. Thousand Oaks: SAGE Publications, 324-38.
Riley PL, Jossy R, Nkinsi L, Buhi L (2001). The Care-CDC Health Initiative: A model for global participatory research. Am J of Public health 91: 1549-52.

Santiago-Riviera AL, Morse GS, Hunt A, Lickers $H$ (1998). Building Community-Based Research Partnership. Lessons from the Mohawk Nation of Akwesasne. J Community Psychology 26: 163-74.

Smith DE (1999). Writing the Social: Critique, Theory, and Investigations. Toronto: University of Toronto Press.

Sullivan M, Kone A, Senturia KD, Chrisman NJ, Ciske SJ, Krieger JW (2001). Researcher and Researched - Community Perspective: Toward Bridging the Gap. Health Educ Behav 28: 266-83.

Yin RK (2002). Case Study research: Design and Methods. Thousand Oaks, CA: Sage.

Address for correspondence:

Jocelyne Bernier

GRIS/Université de Montréal

C.P. 6128

Succ. Centre-ville

Montréal (Québec)Canada, H3C 3J7. e-mail: jocelyne.bernier@UMontreal.CA 